\title{
RELASI OTONOMI KHUSUS DAN PENGURANGAN KEMISKINAN DI PROVINSI ACEH
}

\author{
Ikhsan
}

\author{
Email: Ikhsan.Baharudin@yahoo.com
}

\begin{abstract}
This study investigates the The relationship between special autonomi and impact of alleviation of poverty. Special autonomy in Aceh was designed to rebuild Aceh Post-Conflict and tsunami that had destroyed Aceh from the development and social political causing increased poor people. Special autonomy expected to be the solution of social problems and poverty in aceh province.To achieve a purpose of this research, used the theory decentralization asymmetrical that helps to see efforts pelaksaan decentralization at the provincial level in accordance with local knowledge to the problem of community social and confinement the level of poverty.This research uses the method the qualitative study by adopting descriptive aimed at to explain deeper on the impact of autonomy special on alleviation of poverty through technique observation, interviews and documentation. the results showed that the relationship between special autonomy and poverty has no significant effect
\end{abstract}

Keyword : Special autonomy, poverty, policy, relationship

\section{PENDAHULUAN}

\section{Latar Belakang}

Kemiskinan telah menjadi isu global yang dapat menghambat kesejahteraan dan kemajuan peradaban umat manusia, bahkan Badan Pusat Statistik (BPS) mencatat hingga bulan Maret 2014 jumlah penduduk miskin di Indonesia menembus angka 28,28 juta jiwa atau 11,47 persen dari total penduduk Indonesia. Menurut banyak pakar kemiskinan, faktor ekonomi sering kali disebut sebagai penyebab utama munculnya kemiskinan. Namun pada kenyataannya, faktor politik adalah faktor yang paling dominan memainkan peranan bagi munculnya penduduk miskin baru akibat berbagai kebijakan yang dibuat. Selain itu, faktor pendidikan yang rendah, dan faktor infrastruktur yang terbatas menjadi penyebab makin banyaknya kemiskinan di Indonesia. . Meskipun memiliki sumber daya alam yang berlimpah namun apabila hidup di daerah yang tertinggal dengan infrastruktur yang terbatas maka besar kemungkinan individu tersebut akan 
tetap terjebak dalam lingkaran kemiskinan.

Ketimpangan ekonomi yang berujung pada konflik disintegrasi terjadi di beberapa daerah di Indonesia, seperti pemberontakan Gerakan Aceh Merdeka (GAM), Organisasi Papua Merdeka (OPM), dan lepasnya timor-timur dari NKRI. Antisipasi yang dilakukan oleh pemerintah adalah dengan menerapkan desentralisasi yang asimetris seperti di Aceh dan Papua berupa otonomi khusus. Menurut Hanum (2001:109) terdapat dua manfaat yang dapat diperoleh dari pemberlakuan desentralisasi asimetris. Pertama, sebagai solusi bagi kemungkinan terjadinya konflik etnis, atau konflik fisik lainnya. Kedua, sebagai respon demokratis dan damai terhadap keluhan atau masalah yang dihadapi kelompok kaum minoritas.

Terkait dengan permasalahan desentralisasi di Aceh, pemerintah telah merespon dengan memberlakukan Undang-Undang Nomor 11 tahun 2006 tentang Pemerintah Aceh dengan alokasi dana otonomi khusus tahun 2008 adalah sebesar Rp3,59 Triliun dan terus meningkat setiap tahunnya sesuai perkembangan DAU Nasional. Total dana otsus yang sudah diterima Aceh sampai tahun 2014 adalah sebesar Rp 35,1 Triliun.

Jumlah dana otsus yang sudah diterima merupakan jumlah yang sangat besar untuk bisa dimanfaatkan untuk pembangunan guna meningkatkan kesejahteraan masyarakat Aceh. Dalam rangka pengentasan kemiskinan. Hal ini sesuai pernyataan Gubernur Aceh:

"Didasarkan data BPS Aceh, angka kemiskinan di Aceh saat ini sebesar 19,72 persen dan dengan dana yang dimiliki Aceh, serta program dan kegiatan yang akan dijalankan tahun ini, pemerintah optimis akan terjadi penurunan kemiskinan sebesar 2 (dua) persen" (www.bisnisaceh.com, 2014).

Otonomi khusus Aceh dipandang dapat mengurangi kemiskinan dengan lebih cepat apabila didorong oleh tata kelola pemeritahan yang baik. Otonomi khusus di Aceh akan meningkatkan efesiensi alokasi sumberdaya karena pemerintah di daerah lebih dekat dengan warga daripada pemerintah pusat sehingga pemerintah di daerah diharapkan memiliki informasi yang akurat dan bisa menyelesaikan persoalan dengan lebih cepat.

Penelitian ini difokuskan terhadap dampak dari pelaksaan otonomi khusus di Aceh yang telah berjalan selama 7 (Tujuh) tahun terutama terhadap pengurangan kemiskinan sebagai kosekuensi dari kontruksi otonomi khusus di Aceh yaitu pengurangan kemiskinan, selain itu 
penelitian ini dimaksudkan untuk mengetahui apakah penerapan otonomi khusus di Aceh mampu untuk mensejahterakan masyarakat. Pertanyaan dalam penelitian ini adalah Bagaimana hubungan otonomi khusus dan pengurangan kemiskinanan di Propinsi Aceh?

\section{TINJAUAN TEORI}

\section{Tinjauan Pustaka}

Otonomi khusus sebagai salah satu strategi dalam mengatasi persoalan kesejahteraan sosial telah banyak menjadi bahan kajian para ahli. Berikut ini disajikan beberapa tulisan yang mengangkat tema di atas sebagai fokus penelitian. Skonieczny dan Torissi (2008) melakukan penelitian tentang keberadaan daerah-daerah yang diberikan hak otonomi khusus. Penelitian ini berangkat dari kasus otonomi khusus yang yang diberikan kepada salah satu daerah di Spanyol yang dikenal dengan comuniddades autonomas, serta sebuah daerah di Italia yang juga diberikan berupa otonomi khusus.

Untuk memperjelas pemahaman mengenai kemiskinan, berikut penulis lampirkan tabel penelitian terdahulu.

Tabel 2.1 Penelitian Terdahulu Tentang Kemiskinan

\begin{tabular}{|c|c|c|c|}
\hline $\begin{array}{l}\text { Peneliti/ } \\
\text { Tempat }\end{array}$ & $\begin{array}{c}\text { Judul/tempat } \\
\text { penelitian }\end{array}$ & $\begin{array}{c}\text { Metode } \\
\text { Penelitian }\end{array}$ & Hasil/Penelitian \\
\hline $\begin{array}{l}\text { Skonieczny } \\
\text { dan Torissi di } \\
\text { Spanyol dan } \\
\text { Italia (2008) }\end{array}$ & $\begin{array}{lr}\text { Daerah otonomi khusus } \\
\text { dan } r \text { tingkat } \\
\text { keberhasilan } r \text { dalam } \\
\text { pembangunan ekonomi }\end{array}$ & Kualitatif & $\begin{array}{l}\text { Menemukan bahwa terdapat } \\
\text { hubungan antara pemberian } \\
\text { otonomi khusus dengan perubahan } \\
\text { indeks pembangunan ekonomi. }\end{array}$ \\
\hline $\begin{array}{ll}\text { Luthfi } \quad \text { di } \\
\text { Aceh } \\
\text { (2012) }\end{array}$ & 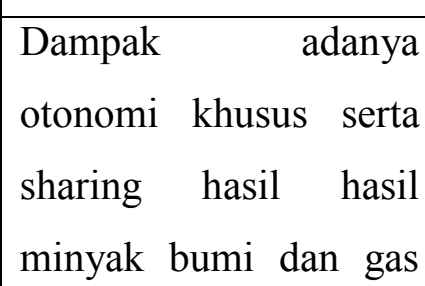 & Kuantitatif & $\begin{array}{lr}\text { Menemukan } & \text { fakta } \\
\text { pengeluaran } & \text { bemerintah } \\
\text { (government expenditure) yang } \\
\text { meningkat secara signifikan sejak }\end{array}$ \\
\hline
\end{tabular}




\begin{tabular}{|c|c|c|c|}
\hline & $\begin{array}{l}\text { (dan amigas) terhadap } \\
\text { program pengurangan } \\
\text { angka kemiskinan di } \\
\text { Aceh }\end{array}$ & & $\begin{array}{l}2009 \text { tidak diikuti dengan } \\
\text { peningkan taraf kesejahteraan } \\
\text { masyarakat, meskipun angka } \\
\text { pengangguran berhasil diturunkan. }\end{array}$ \\
\hline $\begin{array}{l}\text { Mollet di } \\
\text { Papua } \\
\text { (2012) }\end{array}$ & $\begin{array}{l}\text { Otonomi } \\
\text { phogusus dan } \\
\text { kemiskinan di Provinsi } \\
\text { Papua }\end{array}$ & $\begin{array}{l}\text { Deskriptif } \\
\text { kualitatif }\end{array}$ & $\begin{array}{lccr}\text { Terjadi } & \text { pengurangan } & \text { angka } \\
\text { kemiskinan } & \text { di } & \text { provinsi } & \text { Papua } \\
\text { sebesar } & 10 & \% & \text { setelah } \\
\text { dibelakukannya } & \text { status } & \text { otonomi } \\
\text { khusus. Angka } & \text { ini } & \text { merupakan } \\
\text { pengurangan kemiskinan } & \text { paling } \\
\text { signifikan dalam } & \text { satu } & \text { dekade } \\
\text { terakhir. } & & & \end{array}$ \\
\hline $\begin{array}{l}\text { Fleinteinstein } \\
\text { dan Iwata di } \\
\text { China (2004) }\end{array}$ & $\begin{array}{l}\text { Pengaruh desentralisasi } \\
\text { ekonomi dan fiskal } \\
\text { terhadap pertumbuhan } \\
\text { ekonomi dan inflasi di } \\
\text { China. }\end{array}$ & Kuantitatif & $\begin{array}{l}\text { Desentralisasi } \\
\text { berhubungan positif dengan } \\
\text { pertumbuhan PDB riil di China. }\end{array}$ \\
\hline $\begin{array}{l}\text { Hammound } \\
\text { dan Tossun di } \\
\text { Virginia } \\
\text { University } \\
(2009)\end{array}$ & $\begin{array}{l}\text { Keterkaitan antara } \\
\text { otonomi daerah dan } \\
\text { pertumbuhan ekonomi }\end{array}$ & Kualitatif & $\begin{array}{l}\text { Yang menentukan berhasil atau } \\
\text { tidak pembangunan ekonomi tidak } \\
\text { ditentukan oleh bentuk pengelolaan } \\
\text { pemerintah daerah (desentralisasi } \\
\text { atau tidak) tetapi juga bentuk } \\
\text { organisasi pemerintah daerah itu } \\
\text { sendiri }\end{array}$ \\
\hline
\end{tabular}




\section{Kerangka Teori}

\subsection{Desentralisasi}

Menurut UU No. 32 Tahun 2004 tentang Otonomi Daerah, desentralisasi adalah penyerahan wewenang pemerintahan oleh Pemerintah kepada Daerah Otonom dalam kerangka Negara Kesatuan Republik Indonesia. Desentralisasi merupakan salah satu dari upaya penyelenggaraan pemerintahan yang didelegasikan kepada pemerintah daerah, selain dekonsentrasi dan tugas perbantuan. Dekonsentrasi adalah pelimpahan wewenang dari Pemerintah kepada Gubernur sebagai wakil Pemerintah dan atau perangkat pusat di Daerah. Tugas Perbantuan adalah penugasan dari Pemerintah kepada Daerah dan Desa dan dari Daerah ke Desa untuk melaksanakan tugas tertentu yang disertai pembiayaan, sarana dan prasarana, serta sumber daya manusia dengan kewajiban melaporkan dan mempertanggungjawabkan pelaksanaannya kepada yang menugaskan.

Secara umum, ada tiga argument yang senantiasa digunakan untuk menggarisbawahi pentingnya desentralisasi. Pertama, desentralisasi akan meningkatkan efesiensi alokasi sumber daya karena pemerintah didaerah lebih dekat dengan warga ketimbang pemerintah pusat sehingga memiliki informasi yang cepat untuk merespon kebutuhan warga. Hal ini juga mendorong pemerintah daerah untuk berkompetisi, mempromosikan keunggulan daerah masingmasing yang pada akhirnya akan memacu inovasi dan kebijakan yang lebih progesif. Kedua, desentralisasi akan meningkatkan produktivitas melalui peningkatan akuntabilatas, pemberantasan korupsi dan peningkatan efektifitas pemerintah lokal (Ni’matul Huda: 78, 2009)

\subsection{Desentralisasi Asimetris}

Pengadopsian model desentralisasi asimetris didasari kebutuhan akan kerangka administrasi yang handal dalam mengelola keragaman lokal. Format pengorganisasian Negara dilihat sebagai wujud respon atas realitas keberagaman masyarakat sebagai sebagai sumber input bagi bekerjanya sistem politik/pemerintahan. Warsito Utomo (2004) juga menggaris bawahi pentingya melihat desentralisasi asimetris (termasuk yang dipraktekkan Negara federal) sebagai upaya untuk tidak saja melakukan transfer of political outhority tetapi juga upaya untuk mengakomodasi terhadap cultural diversity. Disentralisasi akan memberikan ruang gerak secara cultural bagi daerah yang berkarakter berbeda. Pada titik ini menempatkan desentralisasi asimetrik untuk Indonesia variasi budaya yang sangat beragam akan sangat tepat untuk 
memberkan apresiasi terhadap keberagaman tertentu.

\subsection{Otonomi Daerah}

Untuk merangkum semua definisi yang ada pasal I Undang-Undang Nomor 32 tentang Pemerintah Daerah menyebutkan definisi otonomi daerah: "kewenangan daerah otonom untuk mengatur dan mengurus kepentingan masyarakat setempat menurut prakarsa sendiriberdasarkan aspirasi masyarakat sesuai dengan perturan perundang-undangan”

\subsection{Kebijakan Otonomi Khusus}

Daerah-daerah yang memiliki kekhususan ini biasanya memiliki sentimen kesejarahan yang khusus membedakan dengan daerah lain, sentimen kesejarahan ini kemudian diikuti oleh rasa loyalitas yang tinggi pada devisi sosial dalam suatu teritori secara kuat (Yosmardin dan Ramses, 2008:65). Dalam kasus Aceh, perbedaan mendasar antara penyelenggaraan pemerintahan Aceh dengan penyelengaraan pemerintahan daerah lain ialah titik berat pelaksanaan desentralisasi berada ditingkat propinsi, khususnya terkait dengan pengelolaan hakhak keistimewaan.

Hak-hak istimewa di atas menimbulkan tiga implikasi, yaitu pertama Aceh mendapat akses yang lebih besar terhadap sumber daya, baik sumber daya alam maupun keuangan. Kedua, organisasi pemerintah daerah menjadi lebih besar karena pembentukan lembaga-lembaga baru baik yang termasuk jajaran satuan kerja maupun yang tidak. Ketiga, menguatnya kewenangan gubernur khususnya dalam hal pengelolaan dan distribusi dana otonomi khusus serta dana bagi hasil migas. Implikasi terakhir ini menjadi penentu arah kebijakan pemerintah Aceh dalam mengatasi ketimpangan distribusi pendapatan antar-kabupaten pasca berlakunya otonomi khusus.

\subsection{Kemiskinan}

Patterson dan Scholz mendefinisikan penduduk miskin sebagai sekelompok dalam masyarakat dengan tingkat pendapatan paling rendah dan dengan rencana hidup paling rendah pula. Berangkat dari definisi penduduk miskin ini maka kemiskinan diterjemahkan sebagai kondisi ketika pendapatan (income) yang diperoleh sangat rendah (dibawah garis kemiskinan) sehingga menghilangkan kemampuan untuk menata hidup menjadi lebih baik. UNDP (2008:34) mendefinisiskan kemiskinan tidak hanya menyangkut uang tetapi kegagalan akses akan sumber daya seperti kesehatan, pendidikan dan kesempatan untuk berpartisapasi dalam politik. UNDP 
memasukkan penilaian tidak adanya partisapasi dalam pengambilan kebijakan publik sebagai salah satu indikator kemiskinan.

Berdasarkan jenis, kemiskinan dapat dibagi menjadi empat, yaitu pertama, kemiskinan relatif, kemiskinan absolut, kemiskinan struktural dan kemiskinan kultural (Badrudin, 2012:55) kemiskinan relatif. Kedua, kemiskinan absolut Ketiga, kemiskinan struktural Keempat, kemiskinan kultural.

World Bank (2008) dalam Hendra menyebutkan bahwa penyebab kemiskinan: 1) rendahnya pendapatan dan asset untuk memenuhi kebutuhan dasar; 2) ketidakmapuan bersuara di depan institusi negara dan masyarakat; 3) rentan terhadap gangguan ekonomi (Hendra, 2010:59). Kartasasmita (1996:227) menyebutkan bahwa kemiskinan diakibatkan oleh faktorfaktor sebagai berikut: 1) rendahnya tingkat pendidikan menyebabkan keterbatasan pengembangan diri; 2) rendahnya tingkat kesehatan, dalam hal ini rendahnya kesehatan dan gizi buruk menyebabkan rendahnya daya tahan fisik, daya fikir, dan prakarsa; 3) terbatasnya lapangan kerja; 4) keterisolasian.

Dalam penelitian ini dipersempit jangkauan bahwa penyebab kemiskinan akan digunakan keterbatasasan akses modal, rendahnya sumber daya manusia, rendahnya tingkat kesehatan, serta ketidakmampuan untuk berpartisapasi dalam hal politik untuk menyampaikan aspirasi kepada masyarakat dan Negara.

\section{Metodologi}

Penelitian yang dilakukan dalam penelitian ini adalah penelitian deskriptif kulitatif. Penelitian deskriptif adalah penelitian yang tertuju pada pemecahan masalah-masalah sehingga data-data yang dikumpulkan, disusun dan dijelaskan, dan dianalisa (Surachmad, 1980). Penelitian kualitatif adalah jenis penelitian yang temuan-temuanya tidak diperoleh melalui prosedur statistik atau bentuk hitung lainnya. Data tidak berbentuk angka tetapi banyak berupa narasi, deskripsi, cerita, dokumentasi tertulis, dan tidak tertulis. Penelitian kualitatif berusaha memahami fenomena sosial melalui gambaran holistik terhadap obyek studi pada suatu konteks khusus yang alamiah (Lexy J Moleong, 2005). 
Data dalam penelitian ini meliputi data primer dalam bentuk wawancara dan observasi lansung di Propinsi Aceh yaitu; Gubernur Aceh, Bappeda, Dinas Sosial, TNP2K, dan BPS Aceh. Data sekunder yang peneliti gunakan adalah data-data yang dimiliki oleh Bappeda Aceh, Dinas Sosial Aceh, TNP2K Aceh, dan BPS Aceh, yang berupa hasil penelitian terdahulu, laporan.

\section{Pembahasan}

\section{Kondisi Kemiskinan Di Aceh}

Dalam periode 2008-2014, jumlah penduduk miskin Aceh menurun hingga 9 (sembilan) persen atau mencapai lebih empat ratus ribu jiwa. Lebih jelasnya dapat dilihat pada tabel.

Tabel Persentase Kemiskinan di Aceh Tahun 2008 - 2014

\begin{tabular}{|c|c|c|}
\hline Tahun & Angka Kemiskinan Aceh \% & Angka Kemiskinan Indonesia \% \\
\hline 2008 & $23.53 \%$ & $15.40 \%$ \\
\hline 2009 & $21.80 \%$ & $14.15 \%$ \\
\hline 2010 & $20.98 \%$ & $13.33 \%$ \\
\hline 2011 & $19.57 \%$ & $12.49 \%$ \\
\hline 2012 & $18.48 \%$ & $11.96 \%$ \\
\hline 2013 & $17.72 \%$ & $11.46 \%$ \\
\hline 2014 & $16.98 \%$ & $10.96 \%$ \\
\hline
\end{tabular}

Sumber di olah dari BPS

Mencermati perkembangan data kemiskinan Aceh, sebaran penduduk miskin lebih banyak berada di pedesaan dibandingkan wilayah perkotaan. Tahun 2008 jumlah penduduk miskin di pedesaan berjumlah 864.900 jiwa atau sekitar 79,81 persen dari total penduduk miskin dan di perkotaan hanya sebanyak 218.800 jiwa atau 20,19 persen. Proses penurunan jumlah penduduk miskin ternyata relatif tidak diikuti dengan perubahan komposisi sebaran penduduk miskin. Hingga tahun 2014 persentase penduduk miskin pedesaaan relative stabil di kisaran 79 persen dan di perkotaan hanya pada kisaran 20 persen. (BPS,Aceh dalam angka) 
Tabel Jumlah, Pesentase, Dan Perbandingan Penduduk Miskin Terhadap Jumlah Penduduk di Aceh, 2008-2014

\begin{tabular}{|l|l|l|l|l|l|l|l|l|}
\hline Tahun & \multicolumn{3}{|l|}{$\begin{array}{l}\text { Jumlah } \\
\text { Miskin (000) }\end{array}$} & \multicolumn{2}{|l|}{ Penduduk } & \multicolumn{2}{l}{ \% Penduduk Miskin } & \multicolumn{2}{l}{$\begin{array}{l}\text { Perbandingan } \\
\text { Penduduk Miskin Terhadap } \\
\text { Total Jumlah Penduduk }\end{array}$} \\
\cline { 2 - 10 } & Kota & Desa & K+D & Kota & Desa & K+D & Kota & Desa \\
\hline 2007 & 218,8 & 864,9 & 1083,7 & 18,68 & 29,87 & 26,65 & 20,19 & 79,81 \\
\hline 2008 & 195,8 & 763,9 & 959,7 & 16,67 & 26,30 & 23,53 & 20,40 & 79,60 \\
\hline 2009 & 182,2 & 710,7 & 892,9 & 15,44 & 24,37 & 21,8 & 20,41 & 79,59 \\
\hline 2010 & 173,4 & 688,5 & 861,9 & 14,65 & 23,54 & 20,98 & 20,12 & 79,88 \\
\hline 2011 & 180,4 & 718,6 & 899,19 & 14,80 & 24,47 & 19,57 & 20,27 & 79,73 \\
\hline 2012 & 176,6 & 700,6 & 877,23 & 13,90 & 23,45 & 18,35 & 20,34 & 79,66 \\
\hline 2013 & 164,2 & 695,2 & 859,48 & 12,86 & 22,01 & 17,67 & 20,02 & 78,98 \\
\hline 2014 & 158,04 & 679,3 & 837,42 & 11,36 & 19,19 & 16,98 & 21,11 & 78,99 \\
\hline & & 8 & & & & & & \\
\hline
\end{tabular}

Sumber : diolah dari data BPS Aceh

Permasalahan lain kemiskinan di Aceh adalah besarnya gap antara garis kemiskinan wilayah perkotaan dan wilayah pedesaan. Dalam periode 2008-2014 garis kemiskinan perkotaan meningkat dari Rp 246.375,- menjadi Rp 352.056,- sedangkan di pedesaan meningkat dari hanya Rp 218.143,-- pada tahun 2008 menjadi Rp 310.089,-- pada tahun 2014 (Sumber di olah dari BPS). Hal ini tidak hanya menunjukkan rendahnya tingkat pendapatan di pedesaan melainkan juga menyatakan adanya ketimpangan pendapatan yang cukup besar antara penduduk yang tinggal di perkotaan dan di pedesaan.

\section{Akses Kesehatan}

\subsection{Jaminan Kesehatan Aceh (JKA)}

Pemerintah Aceh mengeluarkan kebijakan jaminanan Kesehatan Aceh (JKA) pada tahun 2010 yang bertujuan untuk meningkatkan derajat kesehatan, mendorong kreatifitas, dan produktifitas masyarakat Aceh Program JKA menjembatani masyarakat Aceh untuk mengakses pelayanan kesehatan. JKA menghilangkan kendala biaya ketika masyarakat Aceh berobat. 
Fasilitas kesehatan pemerintah tidak lagi memungut biaya administrasi maupun biaya pelayanan kesehatan, sejak program ini dilaksanakan (Bappeda, RPJM 2012-2017). Untuk jangka panjang Pemerintah Aceh perlu mengupayakan peningkatan kesejahteraan masyarakat dan penyediaan bahan pokok yang murah sehingga meningkatkan gizi masyarakat, yang pada akhirnya akan membuat masyarakat lebih sehat dan kebal terhadap penyakit (Profil Kesehatan Aceh,2014).

\subsection{Status Kesehatan, Pelayanan Kesehatan, Fasilitas Kesehatan, Sumberdaya Tenaga Kesehatan, dan Kondisi Kesehatan Lingkungan}

Gambaran status kesehatan diuraikan berdasarkan pencapaian beberapa indikator seperti; umur harapan hidup, Angka Kematian Bayi (AKB), Angka Kematian Ibu (AKI), gizi balita dan ibu hamil, serta sebaran penyakit menular. Profil kesehatan tahun 2014 menunjukkan jumlah Rumah Sakit Umum di Aceh sebanyak 49 unit, Puskesmas sebanyak 312 unit dengan pembagian puskesmas rawat inap 138 unit dan puskesmas non rawat inap 174 unit. Secara rasio pembangunan puskesmas di Aceh telah mencukupi dimana seluruh kecamatan telah memiliki puskesmas dengan rasio setiap 100.000 penduduk. Selain fasilitas kesehatan tersebut diatas di Aceh telah tersedia Pos Kesehatan Desa (Poskesdes/Polindes) sejumlah 2.269 (35,16 persen), Pos Pelayanan Terpadu (Posyandu) sebanyak 7.150 unit, dan Puskesmas Pembantu (Pustu) sebanyak 852 unit. Pada tahun 2015 diharapkan pembangunan Poskesdes atau Polindes mencapai 50 persen (Profil Kesehatan Aceh).

Permasalahan tenaga kesehatan di Aceh menyangkut jumlah, kualifikasi yang kurang memadai dan distribusi tenaga kesehatan yang tidak merata.

Menilai keadaan lingkungan sehat ada 4 (empat) indikator yaitu (1) persentase keluarga yang memiliki persediaan air minum sehat, (2) keluarga yang memiliki jamban sehat, (3) persentase keluarga yang mengelola sampah dan (4) keluarga yang mengelola air limbahnya dengan baik. Keadaan ini masih jauh dari yang diharapkan karena situasi lingkungan yang kurang sehat dan perilaku hidup sehat yang masih perlu mendapat perhatian serta kerusakan lingkungan akibat bencana yang demikian parah sehingga indikator keberhasilan program ini belum mencapai target. 


\section{Akses Pendidikan}

Pendidikan merupakan urusan strategis yang masih menjadi kewenangan negara, namun karena keistimewaan dan kekhususan daerah, Pemerintah Aceh memiliki kewenangan untuk menyelenggarakan pendidikan sesuai dengan karakteristik, potensi, dan kebutuhan masyarakat Aceh, yaitu pendidikan yang Islami sebagaimana yang telah ditetapkan dalam Qanun Aceh Nomor 23 Tahun 2002 tentang Penyelenggaraan Pendidikan, yang kemudian direvisi menjadi Qanun No.5 Tahun 2008 tentang Penyelenggaraan Pendidikan.

\subsection{Pemerataan Dan Perluasan Akses Pendidikan}

Ketersediaan dan penyebaran lembaga pendidikan yang memadai dan merata merupakan salah satu faktor penting dalam upaya peningkatan APK/APM. Sampai akhir Tahun 2014, di seluruh Aceh terdapat 1.235 unit TK/RA, 3.938 unit SD/MI/SDLB, 1072 unit SMP/MTs/SMPLB, dan 844 unit SMA/MA/SMALB/SMK (termasuk SMK Kecil dan Kelas Jauh). Pada jenjang SD/MI; 33,06 persen ruang kelas sekolah rusak sedang/ringan dan 24,08 persen rusak berat, pada tingkat SMP/MTs; 19,06 persen rusak sedang/ringan dan 17,19 persen rusak berat, dan pada tingkat SMA/MA; 14,85 persen rusak sedang/ringan dan 10,69 persen rusak berat. Selain pendidikan dasar dan menengah, pemerintah Aceh juga menaruh perhatian terhadap akses layanan pendidikan tinggi. Sampai akhir Tahun 2014, di Aceh telah berdiri 79 perguruan tinggi, yang terdiri dari; 11 unit Perguruan Tinggi Negeri (PTN) dan 68 unit Perguruan Tinggi Swasta (PTS) yang tersebar diseluruh wilayah Aceh (Profil Pendidikan Aceh).

Pemerintah Aceh tidak hanya melakukan program penghapusan buta aksara latin, tetapi juga penghapusan buta aksara Al-Qur'an dengan indikator kemampuan membaca Al-Qur'an dengan baik dan benar. Permasalahan pendidikan tidak hanya menyangkut penyediaan layanan pendidikan formal bagi peserta didik, tetapi juga pembekalan ilmu pengetahuan (knowledge) dan ketrampilan (life skills) bagi setiap anggota masyarakat melalui program Pendidikan Non Formal (PNF) (Profil Pendidikan Aceh). 


\section{Akses Modal}

\subsection{Bantuan Keuangan Peumakmu Gampong (BKPG)}

Program BKPG ini disampaikan rancangan oleh Gubernur Aceh pada tanggal 13 Juli 2008. Program ini merupakan inisiatif pemerintah Aceh untuk meningkatkan kesejahteraan rakyat Aceh melalui pembangunan dan pemberdayaan masyarakat. Dana yang disediakan berjumlah Rp 100 juta per gampong yang pemanfaatannya dilakukan melalui proses perencanan secara mandiri oleh masyarakat. Pemerintah kabupaten/kota wajib mengalokasikan dana pendamping dalam bentuk ADG untuk program ini sebesar minimal Rp 50 juta per gampong. Program ini di maksudkan untuk pengurangan kemiskinan yang sangat besar di Aceh yang hampir 50\% warga Aceh berada di bawah tingkat kemiskinan akibat konflik panjang yang berlangsung nyaris 30 tahun (Bappeda, Aceh 2014).

Kepala Badan Pemberdayaan Masyarakat Desa Aceh mengemukakan beberapa tantangan yang harus dihadapi dalam pelaksanaan program ini. Beliau mengatakan,

"Cakupan program ini cukup besar yaitu, 6379 desa, 276 kecamatan dan 23 kabupaten kota. Oleh karena itu, program ini tidak mungkin dilaksanakan apabila tidak adanya dukungan dari seluruh pihak yang terlibat - baik dari segi pelaksanaannya maupun pengontrolan penyaluran dana". (Wawancara, desember 2014).

Pemerintah Aceh kembali mengalokasikan anggaran Rp 517 milliar Bantuan Keuangan Pemakmue Gampong (BKPG) di tahun 2014. Dana BKPG dialokasikan bagi kepada 6.464 gampong di 289 Kecamatan yang ada di 23 Kabupaten/Kota di Aceh. Jumlah tersebut meningkat bila dibandingkan pada tahun 2012 Rp 445 milliar dan Rp 452 milliar di tahun 2013 lalu. Total dana dari tahun 2008-2014 sebesar 2,50 triliun (Bappeda aceh,2014).

\subsection{Tingkat Pengangguran Terbuka}

Tingkat Pengangguran Terbuka (TPT) merupakan salah satu indikator yang dapat menggambarkan kondisi umum perekonomian suatu wilayah, dan sekaligus memberikan gambaran aktivitas masyarakat dalam mencapai kesejahteraan. TPT diukur berdasarkan 
persentase jumlah angkatan kerja yang tidak bekerja yang dipengaruhi oleh beberapa faktor diantaranya adalah kondisi sosial, budaya, dan ekonomi lingkungan, serta kondisi internal angkatan kerja itu sendiri. Jumlah angkatan kerja di Aceh pada tahun 2014 mencapai 1,897 juta orang mengalami penambahan sekitar 104 ribu orang dari kondisi 2008 yang hanya sebanyak 1,793 juta orang. Sedangkan jumlah penduduk yang bekerja pada tahun 2014 adalah sebanyak 1,732 juta orang atau bertambah sekitar 110 ribu orang dari tahun 2008 yang hanya sebanyak 1,622 juta orang (bps.acehprov.go.id).

Peningkatan jumlah orang yang bekerja lebih besar dari peningkatan jumlah angkatan kerja yang terjadi pada tahun 2014 telah menyebabkan menurunnya TPT di Aceh. Kondisi yang yang sama, juga terjadi selama beberapa tahun sebelumnya, akibat semakin bertambahnya kesempatan kerja dan semakin luasnya lapangan usaha yang tercipta. Semakin kondusifnya keamanan daerah dan semakin baiknya kondisi berbagai sarana dan prasarana daerah, serta semakin terbukanya akses daerah terhadap dunia luar telah mendorong masyarakat untuk lebih berpartisipasi dalam akselerasi pembangunan Aceh. Hal ini ditandai dengan semakin banyaknya tumbuh unit-unit usaha kecil dan menengah baik oleh pelaku-pelaku ekonomi lokal maupun tumbuh melalui kemitraan dengan pengusaha-pengusaha luar daerah dan asing.

Tabel Perkembangan Tingkat Pengangguran Terbuka di Aceh Selama Periode 2006 - 2010

\begin{tabular}{|c|c|}
\hline Tahun & $\begin{array}{c}\text { Tingkat Pengangguran } \\
\text { \% }\end{array}$ \\
\hline 2008 & 10,43 \\
\hline 2009 & 10,11 \\
\hline 2010 & 9,90 \\
\hline 2011 & 9,84 \\
\hline 2012 & 9,56 \\
\hline 2013 & 8,71 \\
\hline 2014 & 8,60 \\
\hline
\end{tabular}

Sumber: BPS Aceh 


\section{Akses dalam Pembuatan Kebijakan}

\subsection{Pembentukan Lembaga Tradisional}

\section{a. Pemerintahan Mukim}

Pemerintahan mukim yang pernah berjaya sejak zaman kesultanan, zaman penjajahan dan diawal kemerdekaan. Kembali diakui sejak diberlakukan Undang-Undang Nomor 18 Tahun 2001 tentang Otonomi khusus bagi Propinsi Daerah Istimewa Aceh sebagai Provinsi Aceh dan dipertegas dengan undang undang Nomor 11 Tahun 2006 tentang Pemerintahan Aceh. Bahwa dengan pemberlakuan Otonomi khusus di Provinsi Aceh, mukim sudah dikukuhkan kembali menjadi lembaga pemerintahan dalam sistem penyelenggaraan pemerintahan daerah di Aceh. Mukim adalah kesatuan masyarakat hukum di Aceh yang terdiri dari beberapa gampong yang mempunyai batas wilayah tertentu dan harta kekayaan sendiri, berkedudukan langsung dibawah Kecamatan/Sagoe Cut atau nama lain yang dipimpin oleh Imuem Mukim (Bappeda Aceh,2014)

\section{Pemerintahan Gampong}

Pemerintah Aceh diberikan kewenangan secara luas dan leluasa untuk menata sistem Pemerintahan Daerah sesuai dengan nilai-nilai luhur masyarakat Aceh sebagaimana diatur dalam Undang-undang Nomor 11 Tahun 2006 tentang Pemerintahan Aceh. Implementasi ketentuan dalam Undang-undang tersebut, sebelumnya telah ditetapkan Qanun (Perda) Provinsi Nanggroe Aceh Darussalam Nomor 5 Tahun 2003 tentang Pemerintahan Gampong. Oleh karena itu di Provinsi Aceh istilah lain dari Desa adalah Gampong. Gampong sebagai kesatuan masyarakat hukum memiliki hak dan kekuasaan dalam mengatur dan mengurus kepentingan masyarakat setempat terutama dalam meningkatkan kesejahteraan masyarakat memiliki peran.

Pemerintahan mukim dan gampong yang diharapkan menjadi katalisator masyarakat dalam menyampaikan aspiranya belum memberikan pengaruh yang signifikan dalam menyalurkan aspirasi masyarakat dalam hal, hal ini mengakibatkan program-program yang dilakukan dalam upaya mengurangi tingkat kemiskinan di gampong belum berjalan maksimal. Pengangguran dan kemiskinan masih berpusat di gampong, hal ini menggambarkan belum optimalnya peran mukim dan gampong yang merupakan garda terdepan dalam pelaksanaan program pemerintah. 


\section{Kesimpulan}

Hampir satu dasawarsa implementasi otonomi khusus di Aceh, namun masih saja banyak masalah yang terjadi. Hal ini merupakan tantangan yang harus dipecahkan dan terus dicari jalan keluarnya agar otonomi khusus dapat terwujud seperti apa yang dicita-citakannya. Dari berbagai pustaka yang ditelaah, sebagian besar dari kajian-kajian tersebut mencoba mengatasi persoalan-persoalan tertentu secara spesifik. Misalnya terkait pembangunan ekonomi.

Pembangunan ekonomi pasca diterapkan Otonomi Khusus belum memberikan dampak seperti yang diharapkan. Mengacu pada berbagai publikasi Badan Pusat Statistik Aceh, sejak tahun 2008 perekonomian Aceh tidak mengalami pertumbuhan yang baik. Jika mengacu pada PDRB Aceh harga berlaku terlihat bahwa sejak tahun 2008 perekonomian Aceh memang pengalami pertumbuhan. Namun jika bercermin kepada PDRB harga konstan terlihat bahwa perekonomian justru bergerak turun. Dengan kata lain inflasi yang terjadi tidak mendorong pertumbuhan ekonomi Aceh menjadi lebih produktif.

Penduduk miskin lebih banyak berada di pedesaan dibandingkan wilayah perkotaan. Tahun 2008 jumlah penduduk miskin di pedesaan berjumlah 864.900 jiwa atau sekitar 79,81 persen dari total penduduk miskin dan di perkotaan hanya sebanyak 218.800 jiwa atau 20,19 persen. Proses penurunan jumlah penduduk miskin ternyata relatif tidak diikuti dengan perubahan komposisi sebaran penduduk miskin.

Hingga tahun 2014 persentase penduduk miskin pedesaaan relative stabil di kisaran 79 persen dan di perkotaan hanya pada kisaran 20 persen. Selama periode 2008-2014 kesenjangan rata-rata pengeluaran masing-masing penduduk miskin Aceh baik yang berada di perkotaan maupun di pedesaan terhadap garis kemiskinan semakin menurun. Namun demikian, walau memiliki garis kemiskinan yang lebih rendah, penduduk miskin di pedesaan relatif lebih miskin dibandingkan penduduk miskin di perkotaan. Hal ini kedalaman kemiskinan pedesaan di Aceh. Lebih lanjut, penyebaran pengeluaran penduduk miskin terhadap rata-ratanya di perkotaan juga lebih rendah daripada pedesaan. Dengan demikian tingkat kemiskinan di pedesaan lebih beragam dibandingkan perkotaan atau dengan kata lain tingkat keparahan kemiskinan di perdesaan lebih tinggi dibandingkan keparahan kemiskinan di perkotaan. 


\section{DAFTAR PUSTAKA}

Askhalani, dkk, Korupsi di Negeri Syariat: Catatan Jaringan GeRAK Aceh, Aceh: GeRAK Aceh, 2009.

Badrudin, Rudi, Ekonomika Otonomi Daerah, Yogyakarta: UPP STIM YKPN. 2012.

Boediono, Perekonomian Indonesia, Yogyakarta: BPFE, 1999.

Departemen Keuangan RI, Usulan Formulasi Dana Alokasi Umum Tahun 2002, Jakarta: Indonesia, 2001.

Djohan, D, Desentralisasi Asimetrik di Aceh, Jakarta Jurnal Ilmu Pemerintahan, MIPI, 2006.

Djojosoekarto (ed.), dkk, Grand Strategi Penataan Dsaerah 2025: Bunga Rampai Wacana, Jakarta: Kemitraan, 2008.

Hendra, Roy, Determinan Kemiskinan Absolut di Kabupaten/Kota Provinsi Sumatera Utara Tahun 2005-2007, Tesis 2010.

Kaputra, dkk, Dampak Otonomi Daerah di Indonesia, Jakarta: Yayasan Pustaka Obor, 2013.

Luthfi, A, Impact of Aceh's Additional Budget From Special Autonomy Oil-Gas Revenue Sharing Fund to Poverty Reduction in Aceh, Aceh: ICAIOS's Journal, 2012.

Masyarah, Harry, dkk, Post-Tsunami Aid Effectiveness in Aceh: Proliferation and Coordination In Reconstruction, The Brookings Global Ekonomi and Development Working Paper Series, Washington D.C.: Wolfensohn Center for Development and The Brookings Institute, 2008.

Mollet, Julius Ary, Special Autonomy and Poverty Reduction Programs in Papua: Does it Work?, Papua: Jurnal Universitas Cendrawasih, 2012.

Puskapol, Fisip UI Mencari Model Hubungan Pusat Dan Daerah: Refleksi Otonomi Khusus Aceh, Papua, dan Yogyakarta. Working Paper. 23 February 2009 Draft. Pusat Kajian Politik.

Skonieczny, G, dan Torrisi, B, The Influence of Regional Autonomist Government on the Teritory Environmental and Economics Performances, Journal of Enviromental Economics Volume II 2008.

Todaro, Smith, Pembangunan Ekonomi Edisi Kesembilan, Pearson Education Limited, 2006.

Yosmardin, dkk, Politik Desentralisasi dan Desentralisasi Asimetris, Jakarta, Jurnal Ilmu Pemerintahan, MIPI, 2006. 